\title{
PENGARUH AUDIO MUROTTAL AL-QUR'AN SURAT AR-RAHMAN TERHADAP FAKTOR YANG MEMPENGARUHI LAMA PERSALINAN
}

\author{
Rusfita Retna, Reni Sumanti \\ Program Studi DIII Kebidanan Politeknik Banjarnegara \\ Jl. Raya Madukara KM 02 Kenteng Madukara Banjarnegara Jawa Tengah \\ Email: rusfita.retna@gmail.com
}

\begin{abstract}
ABSTRAK
Lama persalinan yang melebihi batas normal dapat menyebabkan kesakitan pada ibu, persalinan macet dan komplikasi pada janin. Diperlukan startegi sebagai upaya meminimalisir komplikasi persalinan yang dapat menyebabkan kesakitan dan kematian ibu. Tujuan untuk mengetahui pengaruh audio Murottal Al-Qur'an Surat Ar-Rahmaan terhadap faktor yang mempengaruhi lama persalinan di Puskesmas Kabupaten Banjanegara. Metode penelitian ini menggunakan kuantitatif dengan quasy eksperiment dan rancangan post test only control group design dan kualitatif melalui wawancara. Populasi adalah seluruh ibu bersalin di Puskesmas Kabupaten Banjarnegara dengan teknik sampling adalah consecutive sampling. Jumlah sample 30 responden, 15 kelompok intervensi dan 15 kelompok kontrol. Analisa data dengan independent T-Test. Penelitian kualitatif dilakukan wawancara kepada 2 ibu bersalin kelompok kontrol, 2 ibu bersalin kelompok intervensi dan 2 bidan puskesmas. Hasil penelitian menunjukkan nilai $p$ value sebesar 0,779 yang diartikan tidak ada pengaruh pada kelompok intervensi dengan kelompok kontrol. Berdasarkan analisis data yang dilakukan dapat diketahui bahwa tidak ada pengaruh yang signifikan antara lama persalinan pada kelompok intervensi dengan kelompok kontrol. Hasil penelitian melalui metode kualitatif disebutkan bahwa factor yang mempengaruhi lama persalinan adalah kecemasan dan harapan dalam manajemen persalinan yang mempengaruhi lama persalinan.
\end{abstract}

Kata Kunci: lama persalinan; murotal al-qur'an; kecemasan; harapan

\section{THE EFFECT OF KORAN RECITATION AUDIO SURAH AR-RAHMAN ON INFLUENCING FACTORS OF THE LABOR LENGTH}

\begin{abstract}
Length of labor that exceeds normal limits can cause pain in the mother, obstructed labor and complications in the fetus. A strategy is needed as an effort to minimize childbirth complications that can cause maternal morbidity and mortality. The purpose of this study was to determine the effect of the audio of the Koran recitation audio Surah Ar-Rahman on the factors that affect the length of labor at Banjanegara District Health Center. This research method used quantitative with quasi experiment and post test only control group design and qualitative through interviews. The population was all mothers who gave birth at the Banjarnegara District Health Center with consecutive sampling technique. The number of samples were 30 respondents, 15 intervention groups and 15 control groups. Data analysis with independent T-Test. Qualitative research conducted interviews with 2 mothers in the control group, 2 in the intervention group and 2 midwives at Banjarnegara District Health Center. The results showed a $p$ value of 0.779 which means that there was no effect on the intervention group and the control group. Based on the data analysis, it can be seen that there is no significant effect between the length of labor in the intervention group and the control group. The results of the study through qualitative methods stated that the factors that affect the length of labor are anxiety and expectations in labor management which affect the length of labor.
\end{abstract}

Keywords: duration of labor; Koran recitation audio; anxiety; hope 


\section{LATAR BELAKANG}

Kehamilan, persalinan dan nifas merupakan proses fisiologis artinya setiap perubahan yang terjadi pada wanita selama proses hamil, bersalin dan nifas adalah normal. Namun beberapa kasus dalam setiap proses tersebut ditemukan komplikasi atau keadaan gawat darurat yang memerlukan penanganan kolaborasi medis dan rujukan. Oleh karena itu diperlukan startegi sebagai upaya meminimalisir komplikasi yang tidak dapat diprediksi sebelumnya dan dapat menyebabkan kematian ibu. Angka Kematian Ibu (AKI) menurut WHO adalah banyaknya wanita yang meninggal dari suatu penyebab kematian terkait dengan gangguan kehamilan atau penanganannya (tidak termasuk kecelakaan atau kasus insidentil) selama kehamilan, melahirkan dan dalam masa nifas (42 hari setelah melahirkan) tanpa memperhitungkan lama kehamilan per 100. 000 kelahiran hidup (Kemenkes RI, 2014).

Gambaran tentang proses persalinan telah dijelaskan dalam Al-Qur'an surat Maryam ayat 23 yang artinya: "Kemudian rasa sakit akan melahirkan memaksanya bersandar pada pangkal pohon kurma, dia (maryam) berkata, wahai betapa baiknya aku mati sebelum ini dan aku menjadi seseorang yang tidak diperhatikan dan dilupakan."

Berdasarkan ayat tersebut dapat diketahui bahwa tingkat nyeri pada saat persalinan merupakan rasa sakit yang tidak tertahankan. Nyeri persalinan harus diatasi karena mempengaruhi mekanisme fungsional yang menyebabkan respon stress fisiologis. Nyeri juga menyebabkan aktifitas uterus yang tidak terkoordinasi sehingga persalinan menjadi lebih lama yang akhirnya mengancam kehidupan ibu maupun janin (Alehagen, 2005). Ekspresi sikap juga berubah meliputi peningkatan kecemasan dengan penurunan lapangan persepsi, menangis, mengerang, tangan mengepal dan menggengam serta otot mudah terangsang (Bobak, 2004)

Kecemasan dalam persalinan dapat mempengaruhi kondisi ibu dan janin. Beberapa komplikasi yang bisa terjadi saat persalinan adalah distosia bahu, ruptur uterus, inversi uterus, atonia uteri dan persalinan yang sulit, sakit dan lama yang disebabkan faktor mekanik seperti partus lama atau partus macet yang disebabkan oleh faktor fisik, faktor emosi dan faktor sosial. Salah satu faktor emosi atau psikologis terjadinya partus lama adalah ketakutan dan kecemasan ibu yang tidak teratasi selama melahirkan (Dolea, 2003). Perbedaan waktu persalinan antara wanita yang mengalami ketakutan dengan yang tidak mengalami ketakutan adalah 1 jam 32 menit. Kecemasan yang tidak teratasi juga merupakan prediktor terjadinya nyeri selama melahirkan yang akan mempengaruhi kesehatan ibu dan bayi. Sebaliknya nyeri selama melahirkan juga menyebabkan timbulnya kecemasan, sehingga antara stress, kecemasan, ketakutan dan nyeri merupakan siklus yang berkesinambungan ( Thompson, 2008).

Lama persalinan yang melebihi batas normal dapat menyebabkan kesakitan pada ibu seperti kelelahan sehingga persalinan macet dan komplikasi pada janin dapat menyebabkan kesulitan bernafas, detak jantung lemah bahkan gagal nafas sehingga menyebabkan kematian bayi. Diperlukan upaya untuk mengatasi lama persalinan sesuai asuhan sayang ibu yang bersifat holistik dan non farmakologis. Audio murottal surat Ar-Rahman yang diperdengarkan saat persalinan menjadi salah satu upaya asuhan sayang ibu pada masa persalinan. Surat ArRahman merupakan salah satu surat di dalam Al-Qur'an dengan pengulangan ayat yang sama sebanyak 31 kali sehingga ibu lebih familiar dengan ayat pada surat ini. Berdasarkan identifikasi dan analisis masalah peneliti tertarik untuk melakukan penelitian tentang pengaruh murottal Al-Qur'an terhadap lama persalinan di Puskesmas Kabupaten Banjanegara. Penelitian ini bertujuan untuk mengetahui pengaruh audio Murottal Al-Qur'an Surat Ar-Rahman terhadap lama persalinan di Puskesmas Kabupaten Banjanegara.

\section{METODE}

Penelitian ini menggunakan mix methode; data kuantitatif diperoleh dengan menggunakan quasy eksperiment dan rancangan post test only control group design sedangkan data kualitatif diperoleh dengan wawancara. Lokasi penelitian dilakukan 
di Puskesmas wilayah Kabupaten Banjarnegara yang memberikan pelayanan pertolongan persalinan bulan Mei sampai September 2020. Populasi dalam penelitian ini adalah seluruh ibu bersalin di Puskesmas Kabupaten Banjarnegara dengan teknik sampling adalah consecutive sampling. Jumlah sample 30 responden, 15 kelompok intervensi dan 15 kelompok kontrol. Analisis data dengan independent T-Test.

Penelitian kualitatif dilakukan untuk menggali data pengalaman ibu selama proses persalinan dan faktor yang mempengaruhi lama persalinan. Setiap pasien yang memenuhi kriteria penelitian dimasukkan dalam penelitian sampai dengan jumlah sampel yang dibutuhkan terpenuhi. Kriteria inklusi adalah ibu bersalin yang beragama Islam dan bersedia menjadi sample penelitian dengan diberikan intervensi audio murottal (Ar-Rahman) dan kriteria eksklusi adalah ibu bersalin yang mengalami masalah. Intervensi audio murottal pada ibu bersalin dilakukan ketika ibu memasuki inpartu. Audio diperdengarkan menggunakan perangkat music box dan flashdisk yang sudah di instal audio murottal surat Ar-Rohmaan. Audio tersebut diperdengarkan sampai dengan bayi lahir.

Teknik pengambilan data kuantitatif adalah mengukur lama persalinan pada ibu baik kelompok kontrol maupun intervensi melalui partograf. Data kualitatif diperoleh melalui wawancara mendalam kepada 2 ibu bersalin kelompok kontrol, 2 ibu bersalin kelompok intervensi dan triangulasi data kepada 2 bidan puskesmas. Analisa data bivariat dilakukan dengan independent T-Test untuk mengetahui pengaruh audio Murottal Al-Qur'an terhadap lama persalinan di Puskesmas Kabupaten Banjanegara

\section{HASIL}

Analisis Kuantitatif digunakan untuk mengetahui perbedaan lama persalinan pada ibu bersalin yang diperdengarkan murottal AlQur'an.

Tabel 1.Perbedaan lama persalinan yang diperdengarkan Murottal AI-Qur'an

\begin{tabular}{clccc}
\hline & Murotal & $\mathrm{n}$ & $\mathrm{F}$ & Sig. \\
\hline \multirow{3}{*}{ Persalinan } & Intervensi & 15 & .134 & .779 \\
& Kontrol & 15 & &
\end{tabular}

Hasil penelitian menunjukkan bahwa nilai Sig. (2 tailed) sebesar $0.779>0.05$ maka dapat disimpulkan bahwa tidak ada pengaruh murottal Al-Qur'an yang signifikan terhadap lama persalinan pada kelompok intervensi dengan kelompok kontrol. Berdasarkan analisis data yang dilakukan hasil penelitian menunjukkan tidak ada perbedaan lama persalinan antara kelompok kontrol dengan intervensi.

Analisis kualitatif dilakukan untuk mengkaji persepsi ibu bersalin terhadap murottal AlQur'an surat Ar-Rahman dan juga persepsi bidan sebagai pemberi asuhan pada proses persalinan.

Tabel 2. Karakteristik Informan

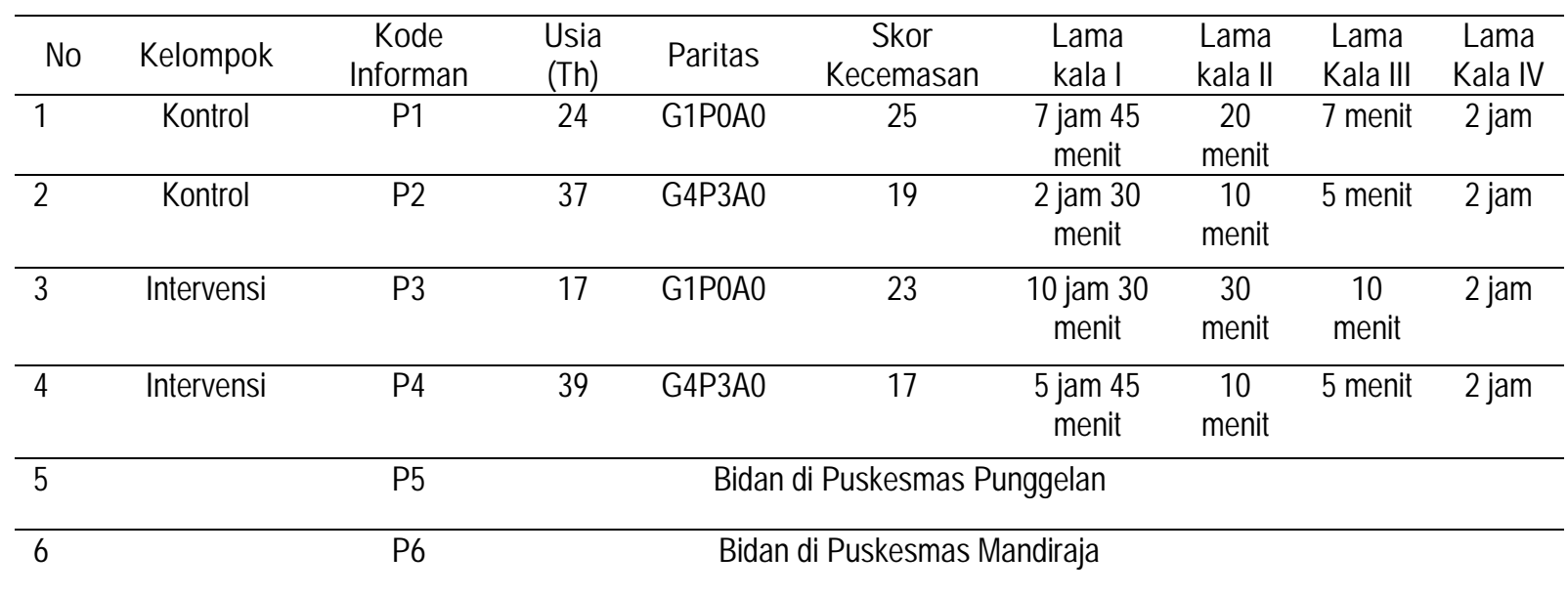


Hasil analisa tema yang dihasilkan oleh peneliti berdasarkan transkrip wawancara dan catatan lapangan dari masing-masing partisipan, peneliti mengidentifikasi pernyataan yang bermakna dan berhubungan dengan fenomena penelitian dan menentukan sub tema dan tema yaitu kecemasan saat persalinan dan harapan terhadap manajemen persalinan.

\section{PEMBAHASAN}

Hasil penelitian menunjukkan tidak ada pengaruh murottal Al-Qur'an terhadap lama persalinan antara kelompok control dengan intervensi. Persalinan adalah suatu proses pengeluaran hasil konsepsi (janin dan uri) yang dapat hidup ke dunia luar dari rahim melalui jalan lahir yang terjadi pada kehamilan aterm / cukup bulan (37-42 minggu), lahir spontan dengan presentasi belakang kepala yang berlangsung dalam 18 jam tanpa komplikasi baik pada ibu maupun janin. Empat fase (kala) persalinan normal: yaitu Kala 1 Fase ini disebut juga kala pembukaan terdiri dari Fase late dan Fase aktif. Rata-rata waktu yang dibutuhkan adalah 18-24 jam. Kala 2 Pada fase ini janin mulai keluar dari dalam kandungan yang membutuhkan waktu sekitar dua jam. Fase dimulai saat serviks sudah membuka selebar $10 \mathrm{~cm}$ hingga bayi lahir lengkap. Kala 3 Tahap ini disebut juga kala uri, yaitu saat plasenta ikut keluar dari dalam rahim. Fase ini dimulai saat bayi lahir lengkap dan diakhiri keluarnya plasenta. Kala 4 Tahap ini merupakan masa dua jam usai persalinan yang bertujuan untuk mengobservasi persalinan.

Lama persalinan setiap ibu bersalin berbeda hal ini dipengaruhi oleh faktor emosi atau psikologis yang dialami ibu bersalin. Penelitian ini dilengkapi dengan mengkaji keadaan psikologis ibu dengan menggunakan data kualitatif melalui wawancara diperoleh tema yang sesuai tujuan penelitian yaitu kecemasan ibu saat bersalin dan harapan manajemen persalinan.

\section{Kecemasan ibu saat persalian}

Proses persalinan dapat menghadirkan berbagai macam emosi pada seorang wanita.
Ketakutan dan kekhawatiran dapat bercampur menjadi satu dengan kegembiraan dan kebahagiaan. Ketegangan, kecemasan, dan ketakutan merupakan faktor yang berkontribusi pada persepsi wanita bersalin tentang nyeri yang dirasakan pada saat bersalin. Ada wanita bersalin yang gelisah dan mengeluh karena merasakan nyeri yang hebat, bahkan ada juga yang sampai berteriak-teriak. Tetapi ada juga wanita bersalin yang bersikap tenang dalam menjalani proses persalinannya. Data ini didukung dengan jawaban hasil wawancara dengan ibu saat persalinan tentang faktor yang mempengaruhi lama persalinan adalah sebagai berikut:

$$
\begin{gathered}
\text { “...saya takut gak bisa lahiran normal..."(P1, P3) } \\
\text { “,., takut nanti bayinya gimana"(P1,P3) } \\
\text { "walaupun udah pernah lahiran tapi ya rasanya } \\
\text { masih khawatir..."(P2, P4) } \\
\text { "rasanya jadi lebih tenang kalau denger ngaji”(P3) } \\
\text { "...kalo lahiran mesti sakit.."(P2) }
\end{gathered}
$$

Keberhasilan penanganan dalam mengatasi kecemasan dengan murottal berbeda-beda antara satu individu yang satu dengan yang lainnya. Hal ini dipengaruhi oleh kebiasaan dan kepribadian individu tersebut. Oleh karena itu kebutuhan dan efektifitas intervensi antara satu dengan yang lainnya juga berbeda-beda. Ibu bersalin yang beragama Islam pasti pernah mendengarkan ayat Al-Qur'an atau pernah mebacanya. Walaupun kebiasaan setiap individu berbeda terhadap Al-Qur'an tetapi Al-Qur'an secara sifat memang telah terbukti sebagai obat (AsSyifa').

\section{Harapan terhadap manajemen persalinan}

Perkembangan ilmu pengetahuan dan teknologi menuntut tenaga kesehatan memberikan pelayanan yang komprehensif kepada pasien. Manajemen persalinan menjadi suatu kebutuhan ibu bersalin dan juga sebagai bentuk pelayanan prima yang diberikan oleh bidan maupun tenaga kesehatan lain yang menolong ibu saat proses persalinan. Kepuasan wanita dengan pengalaman melahirkan secara positif dipengaruhi oleh 
bidan yang memberikan pelayanan, asuhan berkesinambungan, dukungan terus-menerus selama persalinan, kualitas asuhan, dan kualitas dukungan providernya. Hasil transkrip adalah sebagai berikut:

"semoga sih ada metode yang efektif pada masa persalinan" (P5)

"...gak repot si semoga metode ini bias dipakai di sini (puskesmas)" (P2)

Primipara mengalami lama persalinan lebih lama di bandingkan multipara. Metode distraksi menggunakan audio murottal merupakan metode yang baru diterapkan pada proses persalinan. lama persalinan kala I fase laten terjadi dalam waktu selama delapan jam pada primigravida dengan pembukaan satu $\mathrm{cm}$ per 160 menit (2,5 jam) dan pada multigravida terjadi selama 4,5 jam dengan pembukaan satu cm per 90 menit (1,5 jam) (Prawiroharjo, 2010). Beragamnya irama yang digunakan untuk membaca Al-Quran dapat menimbulkan pengalaman yang baru bagi yang mendengarnya. Walupun demikian, bagi ibu bersalin yang beragama islam sekurangkurangnya pernah mendengarkan murottal AlQur'an baik ketika hamil maupun saat sebelum hamil. Hasil transkrip wawancara dari responden tentang pengalaman mendengarkan murottal Surat Ar-Rahman adalah sebagai berikut:

"...ayat yang tadi (murottal surat Ar-Rahmaan) pernah dengar sih..." (P3, P4)

Terapi bacaan Al-Qur'an ketika diperdengarkan pada orang atau pasien akan membawa gelombang suara dan mendorong otak untuk memproduksi zat kimia yang disebut neuropeptide. Molekul ini akan mempengaruhi reseptor-reseptor didalam tubuh sehingga hasilnya tubuh merasa nyaman. Perubahan teknologi yang sangat pesat menuntut bidan untuk memberikan asuhan kebidanan berdasarkan Evidence Based Practice (EBP) dan Health Technology Assessment (HTA). Terapi Al-Qur'an menjadi salah satu terapi komplementer karena membaca atau mendengarkan Al-Qur'an akan memberikan efek relaksasi, sehingga pembuluh darah nadi dan denyut jantung mengalami penurunan (Alkahel, 2011).

\section{KESIMPULAN DAN SARAN}

Tidak ada perbedaan yang signifikan lama persalinan ibu yang diperdengarkan Murottal Al-Qur'an dengan yang tidak diperdengarkan Murottal Al-Qur'an. Hasil penelitian kualitatif teridentifikasi tema yang saling berhubungan dengan tujuan, yaitu kecemasan dan harapan dalam manajemen persalinan. Saran Pelayanan Kesehatan Ibu dan anak di Puskesmas dapat menggunakan metode komplementer non farmakologis khususnya penggunaan audio murottal Al-Qur'an dalam manajemen asuhan persalinan sebagai uapaya mengatasi lama persalinan. Peniliti selanjutnya diharapkan dapat melakukan penelitian true eksperimen dengan jumlah populasi yang lebih besar untuk mendapatkan hasil penelitian yang lebih lengkap.

\section{REFERENSI}

Alehagen, S. et al. Fear, Pain and Stress Hormones During Childbirth. Jounal Psychosom Obstet Gynecol. 2005;

Bobak, M.I., lowdermilk et al. Buku Ajar Keperawatan Maternitas Terjemahan Oleh Wijayarni, M.A dan Anugerah, P.I edisi ke -4. Jakarta: EGC; 2004.

Dolea, C., Abouzahr C. Global burden of obstructed labour in the year. 2000. Evidence and Information for Policy (EIP). In World Health Organization.; 2003.

Thompson DC. Universal Newborn Hearing Screening. In JAMA; 2008.

Alkahel A. No TitleAl-Qur'an 's the Healing. Tarbawi Pr. Jakarta; 2011.

Rohani D. Asuhan Kebidanan pada Masa Persalinan. Jakarta: Salemba Medika; 2010.

Asrinah, Siswoyo S, Nirmala D, Sulistyorini D, Syamrotul I. Asuhan Kebidanan Masa Persalinan. Yogyakarta: Graha IImu; 2010.

Barlow. Intisari Psikologi Abnormal Edisi Keempat. Yogyakarta: Pustaka Pelajar; 2006.

Chaplin J. Kamus Lengkap Psikologi. Jakarta: Rajawali Press; 2004.

RI D. Pelatihan Klinik Asuhan Persalinan Normal. Jakarta: JNPKKR; 2008.

Henderson, C. JK. Buku Ajar Konsep Kebidanan. Jakarta: EGC; 2006.

Agama K. Al-Qur'an dan Terjemahnya. Semarang: TOHA; 2011. 
Retna \& Sumanti., Pengaruh Pengaruh Audio Murottal Al Qur'an....... SJKB, Vol. 8, No.1,Juni 2021, 38-43

Elzaky J. Mukjizat Kesehatan Ibadah. Jakarta: Penerbit Zaman; 2011.

Qadri MA. Quranic Therapy Heal Yourself. USA: Islamic Educational Cultural Research Center of North America; 2003.
Kemenkes, RI. (2014). Psat Data dan Informasi Kementrian Kesehatan RI Tahun 2014. Jakarta: Kemenkes Rl.

Prawirohardjo. (2010). Ilmu Kebidanan. Jakarta: Yayasan Bina Pustaka Sarwono. 